Supplement of Atmos. Chem. Phys. Discuss., 15, 33209-33251, 2015

http://www.atmos-chem-phys-discuss.net/15/33209/2015/

doi:10.5194/acpd-15-33209-2015-supplement

(C) Author(s) 2015. CC Attribution 3.0 License.

(c) (i)

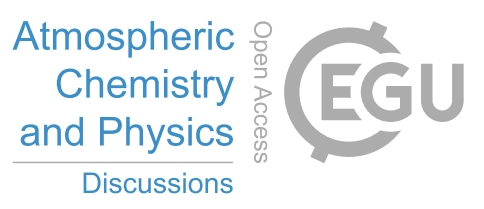

Supplement of

\title{
The impact of monthly variation of the Pacific-North America (PNA) teleconnection pattern on wintertime surface-layer aerosol concentrations in the United States
}

\section{J. Feng et al.}

Correspondence to: H. Liao (hongliao@ mail.iap.ac.cn)

The copyright of individual parts of the supplement might differ from the CC-BY 3.0 licence. 
(a) One Point Correlation Map

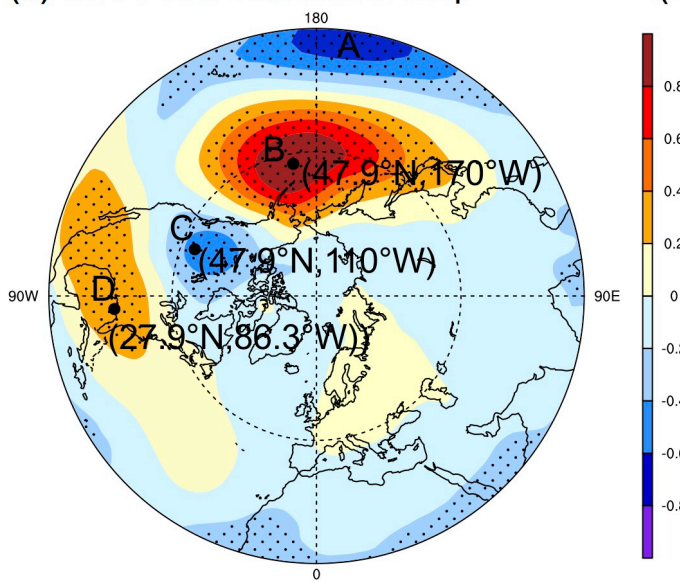

(c) Geopotential Anomalies in PNA+

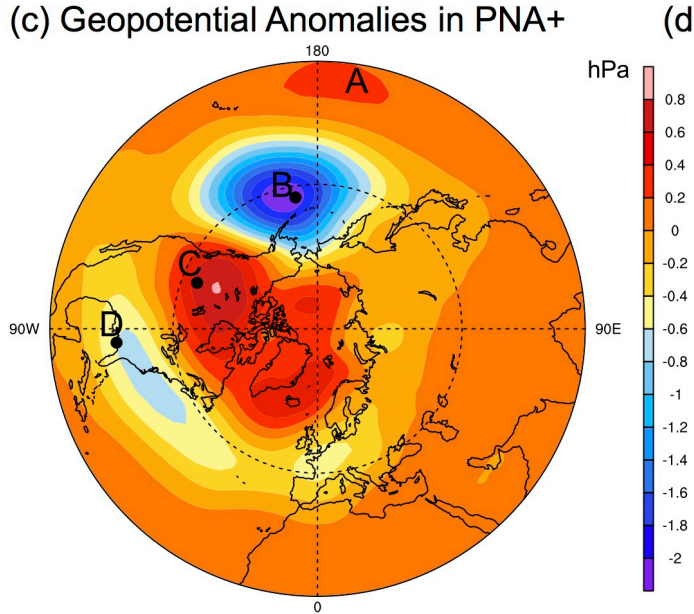

(b) Geopotential Anomalies in PNA-

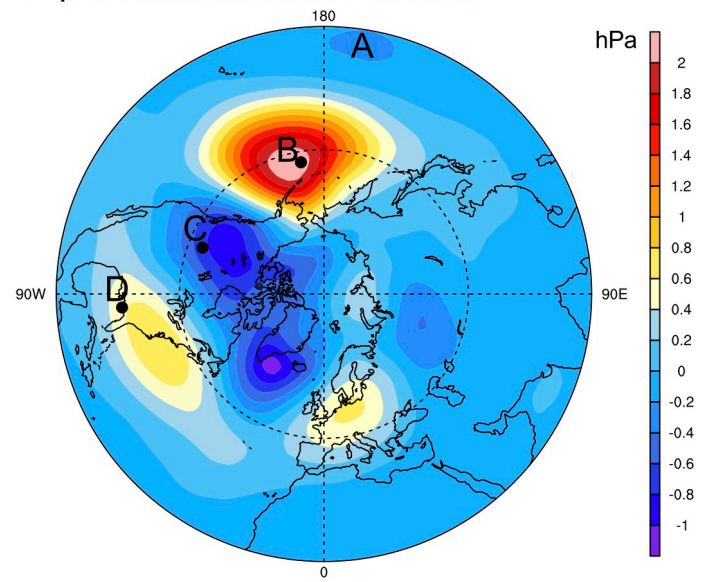

(d) Geopotential Diff. between PNA+ and PNA-

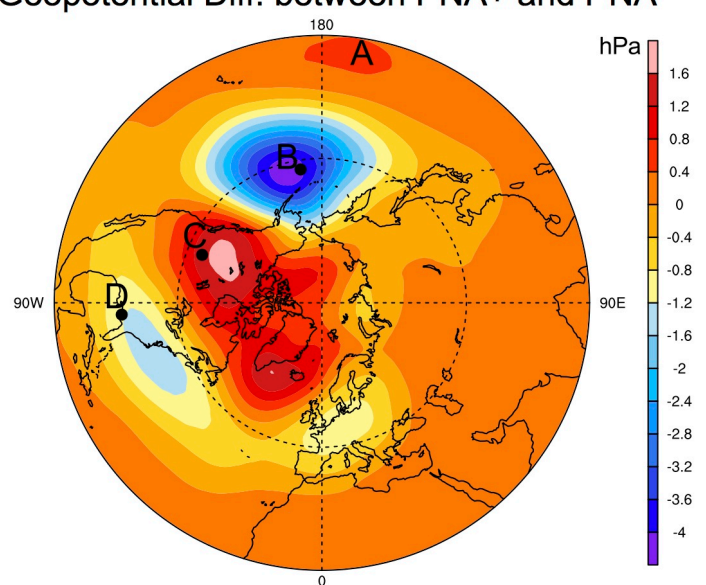

Fig. S1. (a) The correlation coefficients between geopotential height at point $B$ and geopotential heights in other grid cells in the Northern Hemisphere, following Wallace and Gutzler (1981). (b) The average geopotential height in PNA- months minus the average of geopotential height over the months of NDJFM of 1986-2013. (c) The average geopotential height in PNA+ months minus the average of geopotential height over the months of NDJFM of 1986-2013. (d) The average geopotential height in PNA+ months minus that in PNA- months. Datasets used are deseasonalized geopotential heights at $700 \mathrm{hPa}$ from NCEP-2 assimilated data in the months of NDJFM during 1986-2013. See Sect. 2.3 in the manuscript for the calculation of PNA index and the definition of PNA+ and PNA- months.

The dotted areas in (a) denote the regions that have passed the two-tail student-t test with $90 \%$ significance level. As shown in (b) and (c), the PNA pattern comprises positive (negative) geopotential height anomalies in the vicinity of Hawaii (Point $A$ ) and over the intermountain region of North America (Point $C$ ), while negative (positive) geopotential height anomalies in the south of the Aleutian Islands (Point B) and over the Gulf Coast region in the United States (Point D). The PNA has large impacts on meteorological variables in the U.S. in wintertime (Leathers et al. 1991, Notaro et al. 2006). 


\section{References}

Leathers, D. J., Yarnal, B. and Palecki, M. A.: The Pacific/North American Teleconnection Pattern and United States Climate. Part I: Regional Temperature and Precipitation Associations, J. Clim., 4(5), 517-528, doi:10.1175/1520-0442(1991)004<0517:TPATPA>2.0.CO;2, 1991.

Notaro, M., Wang, W.-C. and Gong, W.: Model and Observational Analysis of the Northeast U.S. Regional Climate and Its Relationship to the PNA and NAO Patterns during Early Winter, Mon. Weather Rev., 134(11), 3479-3505, doi:10.1175/MWR3234.1, 2006.

Wallace, J. M. and Gutzler, D. S.: Teleconnections in the Geopotential Height Field during the Northern Hemisphere Winter, Mon. Weather Rev., 109(4), 784-812, doi:10.1175/1520-0493(1981)109<0784:TITGHF>2.0.CO;2, 1981. 